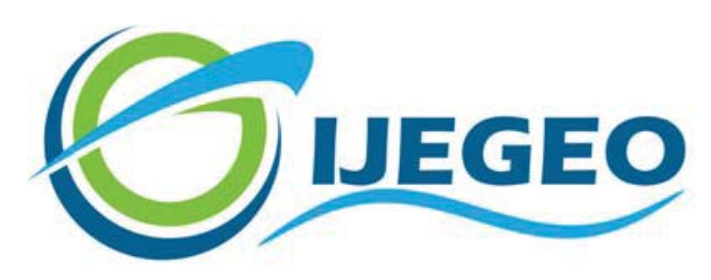

International Journal of Environment and Geoinformatics (IJEGEO) is an international, multidisciplinary, peer reviewed, open access journal.

\title{
Transfer Factors of Natural Radionuclides from Soil to Medicinal Plants used by Local People in Eastern Anatolia, Turkey
}

\section{Gülçin BİLGİĊ CENGİZ, İlyas ÇAĞLAR}

\author{
Chief in Editor \\ Prof. Dr. Cem Gazioğlu \\ Co-Editors Prof. Dr. Dursun Zafer Şeker, Prof. Dr. Şinasi Kaya, \\ Prof. Dr. Ayşegül Tanık and Assist. Prof. Dr. Volkan Demir
}

Editorial Committee (June 2022)

Assoc. Prof. Dr. Abdullah Aksu (TR), Assoc. Prof. Dr. Uğur Algancı (TR), Assoc. Prof. Dr. Aslı Aslan (US), Prof. Dr. Levent Bat (TR), Prof. Dr. Paul Bates (UK), İrşad Bayırhan (TR), Prof. Dr. Bülent

Bayram (TR), Prof. Dr. Luis M. Botana (ES), Prof. Dr. Nuray Çağlar (TR), Prof. Dr. Sukanta Dash (IN), Dr. Soofia T. Elias (UK), Prof. Dr. A. Evren Erginal (TR), Assoc. Prof. Dr. Cüneyt Erenoğlu (TR), Dr. Dieter Fritsch (DE), Prof. Dr. Ç; Prof. Dr. Manik Kalubarme (IN), Dr. Hakan Kaya (TR), Assist. Prof. Dr. Serkan Kükrer (TR), Assoc. Prof. Dr. Maged Marghany (MY); Prof. Dr. Micheal Meadows (ZA), Prof. Dr. Nebiye Musaoğlu (TR), Prof. Dr. Masafumi Nakagawa (JP), Prof. Dr. Hasan Özdemir (TR), Prof. Dr. Chyssy Potsiou (GR), Prof. Dr. Erol Sarı (TR), Prof. Dr. Maria Paradiso (IT), Prof. Dr. Petros Patias (GR), Prof. Dr. Elif Sertel (TR), Prof. Dr. Nüket Sivri (TR), Prof. Dr. Füsun Balık Şanlı (TR), Dr. Duygu Ülker (TR), Prof. Dr. Seyfettin Tsaş (TR), Assoc. Prof. Dr. Ömer Suat Taşkın (TR), Assist. Prof. Dr. Tuba Ünsal (TR), Assist. Prof. Dr. Sibel Zeki (TR) 


\title{
Research Article
}

\section{Transfer Factors of Natural Radionuclides from Soil to Medicinal Plants used by Local People in Eastern Anatolia, Turkey}

\author{
Gülçin Bilgici Cengiz 1,* (D), İlyas Çağlar² (D) \\ ${ }^{1}$ Department of Physics, Faculty of Science and Letters, Kafkas University, Kars, Turkey \\ ${ }^{2}$ Department of Electricity and Energy, Kazım Karabekir Vocational School of Technical Sciences, Kafkas University, Kars, Turkey
}

* Corresponding author: G.BİLGİCİ CENGİZ

Received: 23.06.2021

* E-mail: gulcincengiz@kafkas.edu.tr Accepted: 03.10.2021

How to cite: How to cite: Bilgici Cengiz and Çağlar (2022). Transfer factors of natural radionuclides from soil to medicinal plants used by local people in Eastern Anatolia, Turkey. International Journal of Environment and Geoinformatics (IJEGEO), 9(2): 039-044, doi.10.30897/ ijegeo.956443

\begin{abstract}
Medicinal plants are very useful plants for humans with the various molecules and vitamins they contain. Most of the plants that grow spontaneously in nature were taken into agricultural production practices after their healing properties were discovered. The use of pure active ingredients obtained from plants is quite common. These effective compounds are also used by the pharmaceutical industry in the preparation of modern drug formulations. However, possible high levels of natural radionuclides in medicinal plants, particularly ${ }^{226} \mathrm{Ra},{ }^{232} \mathrm{Th}$ and ${ }^{40} \mathrm{~K}$, have upraised anxieties regarding radiological risks from plant consumption. In this study, the natural radionuclide activity concentrations of 8 commonly used medicinal plants in the Eastern Anatolia Region of Turkey were determined by gamma spectrometric method using $\mathrm{NaI}(\mathrm{Tl})$ detector. The results of the analysis showed that the mean activity concentrations of ${ }^{226} \mathrm{Ra},{ }^{232} \mathrm{Th}$ and ${ }^{40} \mathrm{~K}$ in medicinal plants were $21.05 \pm 2.80 \mathrm{~Bq} \mathrm{~kg}^{-1}, 55.99 \pm 4.32 \mathrm{~Bq} \mathrm{~kg}^{-1}$ and $908.29 \pm 11.86 \mathrm{~Bq} \mathrm{~kg}^{-1}$, respectively. Mean transfer factor (TF) values from soil to plant were found to be $0.59,0.88$ and 1.52 for ${ }^{226} \mathrm{Ra},{ }^{232} \mathrm{Th}$ and ${ }^{40} \mathrm{~K}$, respectively. This present study shows that the use of these examined medicinal plants in the treatment of diseases will not pose any radiological health risks for humans.
\end{abstract}

Keywords: Medicinal plants, Natural radionuclides, Activity concentration, Transfer factor, NaI(Tl) detector

\section{Introduction}

Plants provide the oxygen and nutrients necessary for human life to survive and maintain health. Since the beginning of human history, medicinal herbs have been widely used in all societies and age groups for the treatment of some simple diseases and for people to lead a healthy life. Medicinal and aromatic plants are used in many areas of use such as drugs and cosmetic products used in modern medicine (Acibuca and Bostan Budak, 2018; Akyüz, 2021). Plants convert water, minerals and some elements from the soil into compounds that can be assimilated by the human body in their metabolism. Examples of essential nutrients are carbohydrates, proteins, fats, vitamins, and minerals. These are mainly active substances used in plant metabolism (Faydaoğlu and Sürücüoğlu, 2011; Gazioğlu, 2018).

In spite of the advantages gained from herbs, excess concentrations of uranium, radium, and potassium radionuclide found in consumed plants incline to collect in main body tissues like the lungs, kidneys, thyroid gland, and muscles (Nakamura et al., 2009; Jevremovic et al., 2011). The increase in radionuclide levels in plants and the risk of radiological exposure of living things have prompted researchers in many territories to examine the security of therapeutic plant consumption (Chandrashekara and Somashekarappa, 2016; Monica et al., 2020). Besides the activity concentrations, the soil- to-plant transfer factor (TF) is a significant factor that can be utilized to determine the peripheral influence owing to, radioactivity in the soil. Various studies have been carried out in the world on the transfer of natural radionuclides from soil to plant (Chandrashekara and Somashekarappa, 2015; Saenboonruang, Phonchanthuek and Prasandee, 2018; Asaduzzaman et al., 2014; Jazzar and Thabayneh, 2014). In some studies, the concentration of natural radioactivity and associated effective dose levels for ${ }^{226} \mathrm{Ra},{ }^{232} \mathrm{Th},{ }^{40} \mathrm{~K}$ and ${ }^{137} \mathrm{Cs}$ radioisotopes were measured on agricultural lands, fertilizers and plant samples (grain crops, vegetables, medicinal plants and etc.) from different countries in the world (Al-Hamarneh et al., 2016; Bilgici Cengiz and Çağlar, 2019; Jibiri, and Fasae, 2012; Uchida and Tagami, 2007; Asaduzzaman et al., 2014; Absar et al., 2021; Bilgici Cengiz, 2019; Alfred et al., 2014).

Nowadays, people benefit from the principles brought by modern medicine in the treatment of diseases, but also resort to herbal drugs used in alternative medicine. Plants collected especially by the people living in rural areas in Turkey are used in the treatment of various diseases in the light of beliefs and traditions that have been going on from the past. The purpose of this investigation is to specify the levels of natural radionuclides in soil, which is of great importance in defining the environmental pollution level. Additionally, the aim is to evaluate the transfer factor (TF) from the 
soil to some selected medicinal plants often used in Kars, Turkey and to evaluate the radiological risks related with the usage of these medicinal plants.

\section{Materials and Methods \\ Sample collection and preparation}

Kars, one of the provinces with the highest altitude in Turkey, has an average altitude of 1768 meters. Kars, which has a terrestrial climate, is home to plateaus and mountain meadows, which are considered to be important ecological systems (Figure 1).

Approximately 1250 plants with seeds grow naturally here. 100 of these plants are rare plant species that do not grow anywhere else in the world. For example, Onosma nigricaule examined in this study is one of them. In addition, naturally grown herbs such as Rumeoc patienta, Urtica dioica, Thymus, Rosa canina and Chamomillae romanae are frequently consumed by living things in this region (Özgökçe and Özçelik, 2004). Eight medicinal plants weighing $2 \mathrm{~kg}$ were collected from non-agricultural meadows, forest areas, along streams and local farmers in Kars. The samples were dried in open air for 8 days, afterwards an electrical oven dried in the laboratory at $100{ }^{\circ} \mathrm{C}$ for 3 to 5 hours. The dried samples were then pulverized with a mixer and sieved through a $1 \mathrm{~mm}$ mesh to ensure homogeneity. The powdered samples were placed in radon impermeable polyethylene containers (2.5-inch high and 3-inch diameter), weighed and coded. Soil samples were also collected from the same locations where the plants studied were grown. The examined medicinal plants name and medicinal usage of examined plant parts is shown in Table 1.

Four samples were used for radioactivity measurement in each medicinal plant and corresponding soil. Almost $1.5 \mathrm{~kg}$ of upper layer of soil was taken from per station from a profundity of $7-10 \mathrm{~cm}$ and engaged in nylon bags. Unrelated materials such as root, lapidary, and inorganic residue were removed from soil samples and then soil samples were dried in an oven at $120{ }^{\circ} \mathrm{C}$. The samples were powdered, riddled through a $1 \mathrm{~mm}$ mesh sieve and then closed in airtight polyethylene containers. Both soil samples and medicinal plant samples were stocked in polyethylene containers for 38 days to achieve secular equilibrium between ${ }^{226} \mathrm{Ra}$ and ${ }^{232} \mathrm{Th}$ with their daughter nuclei (Akçay, 2021).

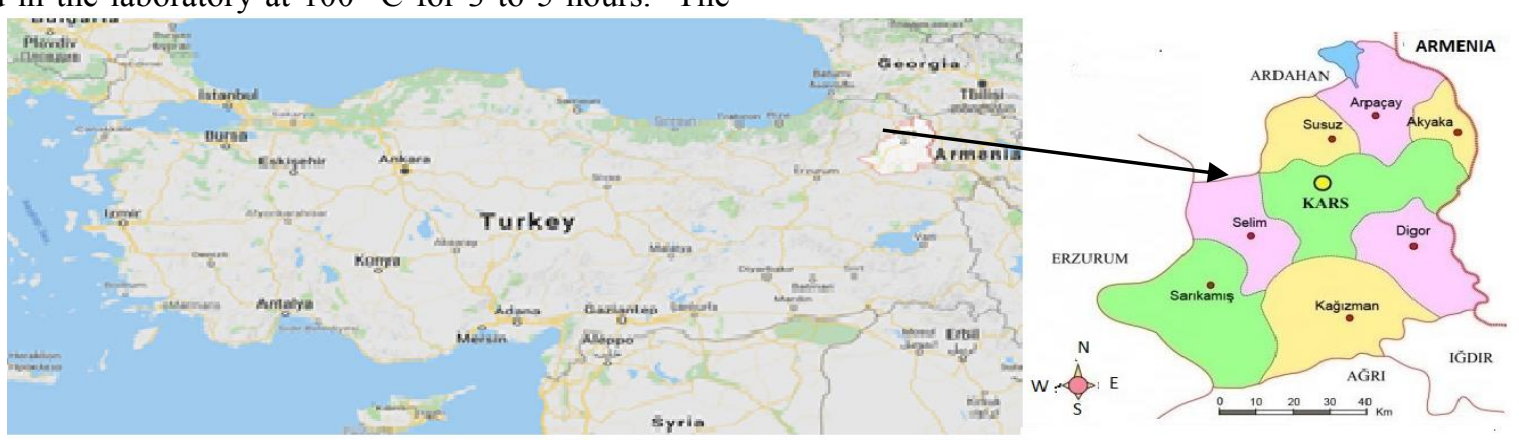

Fig. 1. Map of the studied area

Table 1. The names of medicinal plants examined, the way the plants are grown, the parts of plants examined and their use in medicine

\begin{tabular}{|c|c|c|c|c|}
\hline Name of plant & $\begin{array}{l}\text { Type of } \\
\text { cultivation }\end{array}$ & $\begin{array}{l}\text { Parts } \\
\text { used }\end{array}$ & Medical use & References \\
\hline $\begin{array}{l}\text { Rumeoc } \\
\text { patienta }\end{array}$ & $\begin{array}{l}\text { Naturally } \\
\text { grown }\end{array}$ & Leaves & $\begin{array}{l}\text { skin problems such as eczema, fungus, } \\
\text { strengthening the immune system, rheumatic pain, } \\
\text { menstrual pain }\end{array}$ & $\begin{array}{l}\text { Süleyman et al., } \\
1999\end{array}$ \\
\hline Urtica dioica & $\begin{array}{l}\text { Naturally } \\
\text { grown }\end{array}$ & Leaves & $\begin{array}{l}\text { increasing blood circulation, strengthening the } \\
\text { immune system, protecting against diabetes and } \\
\text { cleaning the blood, oral and dental health }\end{array}$ & $\begin{array}{l}\text { Çolak et al., } \\
\qquad 2020\end{array}$ \\
\hline Thymus & $\begin{array}{l}\text { Naturally } \\
\text { grown }\end{array}$ & Leaves & $\begin{array}{l}\text { appetite enhancer, digestion, worm reducer, removes } \\
\text { gas and urine, psoriasis, coughing attacks and } \\
\text { respiratory tract infections. }\end{array}$ & $\begin{array}{l}\text { Üstü and } \\
\text { Uğurlu, } 2018\end{array}$ \\
\hline Rosa canina & $\begin{array}{l}\text { Naturally } \\
\text { grown }\end{array}$ & Fruit & $\begin{array}{l}\text { kidney disorders, edema, gout, sciatica, diabetes, } \\
\text { anemia, eyes health }\end{array}$ & $\begin{array}{l}\text { Sarıkaya et al., } \\
2010\end{array}$ \\
\hline $\begin{array}{l}\text { Petroselinum } \\
\text { crispum }\end{array}$ & Cultivated & Leaves & $\begin{array}{l}\text { cancer, diabetes, bone weakness, diuretic, bad } \\
\text { breath, nausea. }\end{array}$ & $\begin{array}{l}\text { Akram et al., } \\
2014\end{array}$ \\
\hline Mentha piperita & Cultivated & Leaves & $\begin{array}{l}\text { fatigue, headache, asthma, memory loss, and skin } \\
\text { problems, indigestion }\end{array}$ & $\begin{array}{c}\text { McKay and } \\
\text { Blumberg, } 2006\end{array}$ \\
\hline $\begin{array}{l}\text { Chamomillae } \\
\text { romanae }\end{array}$ & $\begin{array}{l}\text { Naturally } \\
\text { grown }\end{array}$ & Flowers & $\begin{array}{l}\text { menstrual pain, diabetes, slowing osteoporosis, } \\
\text { inflammation, insomnia, digestive system, stomach } \\
\text { ulcer }\end{array}$ & Çalışkan, 2010 \\
\hline $\begin{array}{l}\text { Onosma } \\
\text { nigricaule }\end{array}$ & $\begin{array}{l}\text { Naturally } \\
\text { grown }\end{array}$ & Root & the treatment of wounds and burns & $\begin{array}{l}\text { Bakır et al., } \\
2015\end{array}$ \\
\hline
\end{tabular}




\section{Activity determination}

Radioactivity measurements were made using a $\mathrm{NaI}(\mathrm{Tl})$ detector based on the gamma spectrometry system. Before the measurements, an empty plastic sample container was counted in the same way as the samples to determine the background effects. A calibrated system was used using a standard reference material (IAEA375) prepared by the IAEA (Altzitzoglou and Bohnstedt, 2016). Appropriate photopics at various energies were taken into consideration and the activity concentrations in the medicinal plant samples were determined by selecting the appropriate area (ROI) regions for each peak. The activity concentration ${ }^{226} \mathrm{Ra}$ concentration was detected by evaluating the gamma rays 609.3, 1120.3 and $1764.5 \mathrm{keV}$ from ${ }^{214} \mathrm{Bi}$. Likewise, $583 \mathrm{keV}$ and $2614.5 \mathrm{keV}$ gamma rays from ${ }^{208} \mathrm{~T} 1$ were used to specify the ${ }^{232} \mathrm{Th}$ activity concentration. The ${ }^{40} \mathrm{~K}$ activity concentrations were assessed from the $1460.8 \mathrm{keV}$ gamma line (Biira, Ochom, and Oryema, 2021). Samples were counted over a period of approximately 86400 seconds. The spectrum was analyzed using an MCA (Multi Channel Analyzer) system and a personal computer based on Maestro software (Bilgici Cengiz, 2020).

Plants take water, minerals, some elements and also radionuclides from the soil. The soil-to-plant transfer value was $600.20 \pm 14.3 \mathrm{~Bq} \mathrm{~kg}^{-1}$. The average activity concentration of ${ }^{232} \mathrm{Th}$ and ${ }^{40} \mathrm{~K}$ is estimated to be factor $\left(\mathrm{TF}_{\text {soil-plant }}\right)$ is defined as the transfer of radionuclides from the soil to the plant by plant roots. $\mathrm{TF}_{\text {soil-plant }}$ values were calculated according to Formula 1 using the radionuclide activity concentrations measured of the plant and of the corresponding soil in which this plant grows (Van et al., 2020; Ugbede et al., 2021).

$T F_{\text {soil-plant }}=\frac{A C_{\text {plant }}\left(B q \mathrm{~kg}^{-1}, \text { dry weight }\right)}{A C_{\text {soil }}\left(B q \mathrm{~kg}^{-1}, \text { dry weight }\right)}$

where $\mathrm{TF}_{\text {soil-plant }}, \mathrm{AC}_{\text {plant }}$, and $\mathrm{AC}_{\text {soil }}$ are the transfer factor of the radionuclide, the activity concentrations of the radionuclide in plant samples $\left(\mathrm{Bqkg}^{-1}\right.$, dry weight), and the activity concentrations of the radionuclide in soil samples (Bqkg ${ }^{-1}$, dry weight), respectively.

\section{Results and Discussion}

Activity concentration of radionuclides ${ }^{226} \mathrm{Ra},{ }^{232} \mathrm{Th}$ and ${ }^{40} \mathrm{~K}$ in soil and different parts of plants and their transfer factors of soil to plant are presented in the Table 2.

The ${ }^{226} \mathrm{Ra}$ activity range measured in the surface soil of Kars city in the Eastern Anatolia Region of Turkey was $21.6 \pm 7.0 \mathrm{~Bq} \mathrm{~kg}^{-1}$ to $37.7 \pm 6.8 \mathrm{~Bq} \mathrm{~kg}^{-1}$ and an average of $37.04 \pm 7.9 \mathrm{~Bq} \mathrm{~kg}^{-1}$. The range of measured activity of ${ }^{232} \mathrm{Th}$ for the soil samples was $38.6 \pm 7.5 \mathrm{~Bq} \mathrm{~kg}^{-1}$ to $78.6 \pm 14.9 \mathrm{~Bq} \mathrm{~kg}^{-1}$ with an average of $62.98 \pm 11.6 \mathrm{~Bq}$ $\mathrm{kg}^{-1}$. The ${ }^{40} \mathrm{~K}$ activity concentration ranged from $485.2 \pm 11.3 \mathrm{~Bq} \mathrm{~kg}^{-1}$ to $683.7 \pm 20.5 \mathrm{~Bq} \mathrm{~kg}^{-1}$ and the mean approximately twice and a half times the world average of 30 and $400 \mathrm{~Bq} \mathrm{~kg}^{-1}$, respectively.

Table 2. Average ${ }^{226} \mathrm{Ra},{ }^{232} \mathrm{Th}$ and ${ }^{40} \mathrm{~K}$ activity concentrations (in $\mathrm{Bq} \mathrm{kg}$, dry weight) in medicinal plants and their corresponding soils, and the transfer factors of these radionuclides from the soil to the medicinal plants

\begin{tabular}{|c|c|c|c|c|c|c|c|}
\hline \multirow{2}{*}{ Sample name } & \multirow{2}{*}{ Part of sample } & \multicolumn{3}{|c|}{ Average of activity concentration } & \multicolumn{3}{|c|}{ Transfer factors } \\
\hline & & ${ }^{226} \mathbf{R a}$ & ${ }^{232} \mathrm{Th}$ & ${ }^{40} \mathbf{K}$ & ${ }^{226} \mathrm{Ra}$ & ${ }^{232} \mathrm{Th}$ & ${ }^{40} \mathbf{K}$ \\
\hline \multirow{2}{*}{$\begin{array}{l}\text { Rumeoc } \\
\text { patienta }\end{array}$} & Soil & $37.7 \pm 6.8$ & $49.9 \pm 4.8$ & $683.7 \pm 20.5$ & \multirow{2}{*}{0.48} & \multirow{2}{*}{1.06} & \multirow{2}{*}{1.55} \\
\hline & Leaves & $17.99 \pm 3.2$ & $53.09 \pm 3.2$ & $1056.28 \pm 14.2$ & & & \\
\hline Urtica dioica & $\begin{array}{l}\text { Soil } \\
\text { Leaves }\end{array}$ & $\begin{array}{l}55.7 \pm 8.2 \\
22.82 \pm 3.4\end{array}$ & $\begin{array}{l}61.9 \pm 13.0 \\
59.36 \pm 4.0\end{array}$ & $\begin{array}{l}579.0 \pm 11.8 \\
999.68 \pm 15.0\end{array}$ & 0.41 & 0.96 & 1.73 \\
\hline Thymus & $\begin{array}{l}\text { Soil } \\
\text { Leaves }\end{array}$ & $\begin{array}{l}41.5 \pm 8.6 \\
27.45 \pm 5.2\end{array}$ & $\begin{array}{l}70.4 \pm 12.8 \\
60.98 \pm 4.2\end{array}$ & $\begin{array}{l}630.0 \pm 13.2 \\
828.30 \pm 9.2\end{array}$ & 0.65 & 0.87 & 1.31 \\
\hline \multirow{2}{*}{ Rosa canina } & Soil & $21.6 \pm 7.0$ & $74.5 \pm 13.4$ & $575.2 \pm 13.4$ & \multirow{2}{*}{0.75} & \multirow{2}{*}{0.26} & \multirow{2}{*}{1.38} \\
\hline & Fruit & $16.39 \pm 2.2$ & $19.74 \pm 3.7$ & $795.82 \pm 9.8$ & & & \\
\hline \multirow{2}{*}{$\begin{array}{l}\text { Petroselinum } \\
\text { crispum }\end{array}$} & Soil & $32.5 \pm 8.5$ & $73.6 \pm 13.3$ & $624.0 \pm 23.3$ & \multirow{2}{*}{0.64} & \multirow{2}{*}{1.15} & \multirow{2}{*}{1.52} \\
\hline & Leaves & $21.03 \pm 4.1$ & $85.01 \pm 5.6$ & $949.23 \pm 15.2$ & & & \\
\hline \multirow{2}{*}{$\begin{array}{l}\text { Mentha } \\
\text { piperita }\end{array}$} & Soil & $45.8 \pm 8.4$ & $56.3 \pm 13.2$ & $666.5 \pm 9.2$ & \multirow{2}{*}{0.44} & \multirow{2}{*}{1.15} & \multirow{2}{*}{1.40} \\
\hline & Leaves & $20.22 \pm 3.2$ & $64.26 \pm 4.1$ & $934.87 \pm 16.3$ & & & \\
\hline \multirow{2}{*}{$\begin{array}{l}\text { Chamomillae } \\
\text { romanae }\end{array}$} & Soil & $31.8 \pm 7.5$ & $78.6 \pm 14.9$ & $558.0 \pm 11.7$ & \multirow{2}{*}{1.02} & \multirow{2}{*}{1.07} & \multirow{2}{*}{1.73} \\
\hline & Flowers & $32.76 \pm 3.5$ & $84.82 \pm 5.2$ & $965.20 \pm 18.2$ & & & \\
\hline \multirow{2}{*}{$\begin{array}{l}\text { Onosma } \\
\text { nigricaule }\end{array}$} & Soil & $29.7 \pm 8.9$ & $38.6 \pm 7.5$ & $485.2 \pm 11.3$ & \multirow{2}{*}{0.32} & \multirow{2}{*}{0.53} & \multirow{2}{*}{1.52} \\
\hline & Root & $9.74 \pm 3.8$ & $20.63 \pm 5.4$ & $736.90 \pm 42.0$ & & & \\
\hline
\end{tabular}


However, the average activity concentration of ${ }^{226} \mathrm{Ra}$ was found to be similar to the world average value of $35 \mathrm{~Bq}$ $\mathrm{kg}^{-1}$ (Mehra et al., 2007).

The activity concentration of ${ }^{226} \mathrm{Ra}$ in the medicinal plants ranges from $9.74 \pm 3.8 \mathrm{~Bq} \mathrm{~kg}{ }^{-1}$ (Onosma nigricaule) to $32.76 \pm 3.5 \mathrm{~Bq} \mathrm{~kg}$ (Chamomillae $^{-1}$ romanae) with an average value of $21.05 \pm 2.80 \mathrm{~Bq} \mathrm{~kg}^{-1}$. For the activity concentration of ${ }^{232} \mathrm{Th}$, it varied from 19.74 $\pm 3.7 \mathrm{~Bq} \mathrm{~kg}^{-1}$ (Rosa canina) to $85.01 \pm 5.6 \mathrm{~Bq} \mathrm{~kg}^{-1}$ (Petroselinum crispum) with an average value of $55.99 \pm 4.32 \mathrm{~Bq} \mathrm{~kg}^{-1}$ in the medicinal plants. The ${ }^{40} \mathrm{~K}$ activity concentration were ranged from $736.90 \pm 42.0$ in Onosma nigricaule to $1056.28 \pm 14.2 \mathrm{~Bq} \mathrm{~kg}^{-1}$ in Rumeoc patienta with an average value of $908.29 \pm 11.86 \mathrm{~Bq} \mathrm{~kg}^{-1}$. The radioactivity content of various medicinal herbs has been extensively studied in different parts of the world. The results obtained in this study show that the average values of ${ }^{226} \mathrm{Ra},{ }^{232} \mathrm{Th}$ and ${ }^{40} \mathrm{~K}$ in Urtica diocia are higher than the values reported in Serbia (Djelic et al., 2016). Mean activity concentration values for ${ }^{226} \mathrm{Ra}$ in Petroselium sativum and Tymus plants in Egypt were found to be 42 and $90.88 \mathrm{Bqkg}^{-1}$, respectively, and these values were higher than the values calculated for the same herbs in this study (Ahmed et al., 2010). Furthermore, ${ }^{40} \mathrm{~K}$ concentrations in medicinal plants have been found to be higher than concentrations in medicinal plants in other countries (Desideri, Meli and Roselli, 2010; Najam, Tafiq and Kitah, 2015).

TF values for ${ }^{226} \mathrm{Ra},{ }^{232} \mathrm{Th}$ and ${ }^{40} \mathrm{~K}$ were found to have the ranges of $0.32-1.02,0.26-1.15$, and $1.31-1.73$ with average values of $0.32,0.88$, and 1.52 , respectively. The maximum TF for ${ }^{226} \mathrm{Ra}$ was found in Chamomillae romanae and the minimum value in Onosma nigricaule. It was observed that the accumulation of ${ }^{226} \mathrm{Ra}$ in medicinal plants was higher in flowers than in the leaves and roots of the plants examined. As can be seen from Table 2, it was found that the ${ }^{232} \mathrm{Th}$ radionuclide $\mathrm{TF}$ value from the soil to the leaf part of the plants was higher than the fruit and root parts of the plants. In the root, leaf and flower parts of the plants studied, the average in the root, leaf and flower parts of the plants studied, the average TF values for ${ }^{40} \mathrm{~K}$ are significantly higher than the TF values of other radionuclides, indicating higher ${ }^{40} \mathrm{~K}$ uptake levels.

Djelic et al. reported that the average TF values for ${ }^{226} \mathrm{Ra},{ }^{232} \mathrm{Th}$ and ${ }^{40} \mathrm{~K}$ from soil to their examined medicinal plants were $0.632,0.320$ and 1.760 , respectively. When compared these reported results with the results we obtained from this study on medicinal plants (Urtica dioica, Rosa canina, Chamomillae romanae, and Mentha piperita), the results were in good agreement meantime TFs of ${ }^{40} \mathrm{~K}$ were in similarity. The average ${ }^{226} \mathrm{Ra}$ transfer factors from soil to medicinal plants spied out in this search were approximately twice as large as these reported values. Furthermore, they found the TF average value of thorium in medicinal plants is 0.320 , which is inferior than the results acquired in this present search (Djelic et al., 2016).
The results obtained in the current study for medicinal plants are higher than the published TF average value (0.011) for thorium in grasses. (IAEA 1994). The mean value of ${ }^{40} \mathrm{~K}$ transfer factors noticed in this search is larger than the values reported in the published works in several plants such as vegetables and fruits (Abdou, Hegazy and Eissa, 2017; Shayeb et al., 2017).

The variations in the geologic position of the soils where medicinal plants are grown or planted and the radiochemical properties of these soils can be shown as the reason for the differences found in the measurement of the activity concentrations of the plants. In plants grown in the same field, the activity concentration levels of natural radionuclides may vary because the TF value for different plants is different. Additionally, some studies have found that even different parts of the same plant have different TF values (Chandrashekara and Somashekarappa, 2015, Jazzar and Thabayneh, 2014).

\section{Conclusion}

In this study, the activity concentrations of ${ }^{226} \mathrm{Ra},{ }^{232} \mathrm{Th}$ and ${ }^{40} \mathrm{~K}$ in some selected medicinal plants and related soils where the plants are grown and the transfer factor (TF) from the soil to the medicinal plants were evaluated using gamma ray spectrometry. The results from this study agree well with the literature when compared with previous reports on various herbs that have been extensively studied in different parts of the world. Comparing our results, the average activity concentrations of radionuclides in medicinal plants showed that this ranking was ${ }^{40} \mathrm{~K}>{ }^{232} \mathrm{Th}>{ }^{226} \mathrm{Ra}$. The ${ }^{40} \mathrm{~K}$ activity concentrations ranged from $736.90 \pm 42.0$ to $1056.28 \pm 14.2 \mathrm{~Bq} \mathrm{~kg}^{-1}$ in the plants studied; the concentration trend of this radionuclide was determined as leaves $=$ flowers $>$ roots $>$ fruits. ${ }^{232} \mathrm{Th}$ ranged between $19.74 \pm 3.7$ and $85.01 \pm 5.6 \mathrm{~Bq} \mathrm{~kg}^{-1}$; the concentration trend of these radionuclides is the following: flowers = leaves $>$ roots $>$ fruits.

Also, as a result of calculating the soil-to-medicinal plant transfer factor (TF) for all samples, both Urtica dioica and Chamomillae romanae plants had maximum TF $\left(1.73\right.$ for $\left.{ }^{40} \mathrm{~K}\right)$ while Rosa canina was minimum ( 0.26 for ${ }^{232} \mathrm{Th}$ ). Leaves and flowers had higher TFs than fruits and roots, while ${ }^{40} \mathrm{~K}$ for TFs were higher than TF of ${ }^{226} \mathrm{Ra}$ and also ${ }^{232} \mathrm{Th}$.

As a result of this study, which was carried out to determine the level of natural radioactivity concentrations in different parts of these medicinal plants used by the public in the treatment of diseases, it was determined that people would not be exposed to any radiological health risks due to the use of these plants. The results of this study can be used by appropriate authorities to provide initial values that may be useful in making regulations for radiation protection. It may be used in various research institutes to conduct breeding research of different medicinal plants and also to develop standards for the use of medicinal plants of pharmaceutical production. 


\section{References}

Abdou, N.Y., Hegazy, R.A., Eissa, H.S. (2017). Measurement of gamma activity from clay soil and the leaves of Jew's-mallow plant enhanced by fertilizers. World Appl. Sci. J 35(1):128-136. doi:10.5829/idosi.wasj.2017.128.136

Absar, N., Abedin, J., Rahman, MM., Miah, M.M.H., Siddique, N., Kamal, M., Chowdhury, M.I., Sulieman, A.A.M., Faruque, M.R.I., Khandaker, M.U., et al. (2021). Radionuclides Transfer from Soil to Tea Leaves and Estimation of Committed Effective Dose to the Bangladesh Populace. Life, 11, 282. doi.10.3390/ life 11040282

Acibuca, V. and Bostan Budak, D. (2018). Place and Importance of Medicinal and Aromatic Plants in the World and Turkey. Çukurova J. Agric. Food Sci. 33 (1):37-44.

Ahmed, F., Daif, M.M., El-Masry, N.M., Abo-Elmagd, M. (2010). External and internal radiation exposure of herbal plants used in Egypt. Radiat. Eff. Def. Solids. $\quad$ 65, 65-71, doi.10.1080/ 10420150903428054.

Akçay, N. (2021). On the 30th anniversary of the Chernobyl Nuclear Power Plant Accident, assessment of the activity concentrations and the radiological hazard parameters of soil samples collected from Rize province and districts. Appl. Radiat. Isot. 168, 109435, doi.10.1016/j.apradiso.2020.109435

Akram, M., Hamid, A., Khalil, A., Ghaffar, A., Tayyaba, N., Saeed, A., Ali, M., Naveed, A. (2014). Review on medicinal uses, pharmacological, phytochemistry and immunomodulatory activity of plants. International journal of immunopathology and pharmacology. 27(3), 313-319. doi.10.1177/039463201402700301

Akyüz, E. (2021). Environmental Justice and Nuclear Accidents: The Case of Chernobyl Disaster, International Journal of Environment and Geoinformatics, 8(3), 369-375, doi. 10.30897/ ijegeo.868987

Alfred, A., Koudou, D., Jean-Claude, B. (2021) Determination of Natural Radioactivity of the Hibiscus sabdariffa Linn (Roselle) Used in Côte d'Ivoire (Ivory Coast). Advances in Materials Physics and Chemistry, 11, 59-66. doi.10.4236/ampc.2021.113006.

Al-Hamarneh İ.F., Alkhomashi N., Almasoud F.I. (2016). Study on the radioactivity and soil-to-plant transfer factor of ${ }^{226} \mathrm{Ra},{ }^{234} \mathrm{U}$ and ${ }^{238} \mathrm{U}$ radionuclides in irrigated farms from the Northwestern Saudi Arabia. Journal of Environmental Radioactivity, 160, 1-7,doi.10.1016/j.jenvrad.2016.04.012

Altzitzoglou, T., Bohnstedt, A. (2016). Characterisation of the IAEA-375 Soil Reference Material for radioactivity. Appl. Radiat. Isot. 109, 118-121. doi.10.1016/j.apradiso.2015.11.053

Asaduzzaman, K., Khandaker, M.U., Amin, Y.M., Bradley, D.A., Mahat, R.H., Nor, R.M. (2014). Soilto-root vegetable transfer factors for ${ }^{226} \mathrm{Ra},{ }^{232} \mathrm{Th},{ }^{40} \mathrm{~K}$, and ${ }^{88} \mathrm{Y}$ in Malaysia. J. Environ. Radioact. 135, 20127. doi:10.1016/j.jenvrad.2014.04.009
Bakır, B., Eliș Yıldız, S., Erdağ, D., Sözmen, M., Asker, H. (2016). Immunohistochemical Examination on the Effects of Malathion and Onosma Nigricaule (Boraginaceae) on the Leptin in Renal Tissues of Mice. International Journal of Basic and Clinical Medicine, 3(2), 60-65.

Biira, S., Ochom, P., Oryema, B. (2021). Evaluation of radionuclide concentrations and average annual committed effective dose due to medicinal plants and soils commonly consumed by pregnant women in Osukuru, Tororo (Uganda). J. Environ. Radioact. 227, 106460

Bilgici Cengiz, G. (2019). Transfer factors of 226Ra, $232 \mathrm{Th}$ and $40 \mathrm{~K}$ from soil to pasture-grass in the northeastern of Turkey. Journal of Radioanalytical and Nuclear Chemistry, 319, 83-89, doi.10.1007/s10967-018-6337-8

Bilgici Cengiz, G. (2020). Determination of natural radioactivity in products of animals fed with grass: A case study for Kars Region, Turkey. Scientific reports 10(1), 6939 .

Bilgici Cengiz, G., Çağlar, İ. (2019). Doğu Anadolu'da Kullanılan Bazı Gübrelerin Doğal Radyoaktivite Konsantrasyonlarının Belirlenmesi. Caucasian Journal of Science, 6 (2), 147-155.

Çalışkan, D. (2010) Papatya olarak satılan bitkiler üzerinde fitoterapötik çalışmalar. Türkiye Cumhuriyeti Gazi Üniversitesi Sağlık Bilimleri Enstitüsü Farmakognozi Anabilim Dalı Fitoterapi Programı Yüksek Lisans Tezi;

Chandrashekara, K., Somashekarappa, H. (2015). Soil to plant transfer factors of radionuclides in Ficus racemosa (L.): A medicinal plant. Int. Res. J. Biol. Sci. 4(9), 43-47.

Chandrashekara, K., Somashekarappa, H.M. (2016). Estimation of radionuclides concentration and average annual committed effective dose due to ingestion for some selected medicinal plants of South India. J. Radiat. Res. Appl. Sci., 9, 68-77.

Çolak, S., Çömlekcioğlu, N., Aygan, A. (2020). Urtica dioica Bitki Özütlerinin Antioksidan ve Antimikrobiyal Aktivitelerinin İncelenmesi. Eurasian Journal of Biological and Chemical Sciences, 3 (Ek say1 1), 206-212.

Desideri, D., Meli, M. A., Roselli, C. (2010). Natural and artificial radioactivity determination of some medicinal plants. J. Environ. Radioact., 101, 751756. doi.10.1016/j.jenvrad.2010.04.018

Djelic, G., Krstic, D., Stajic, J.M., Milenkovic, B., Topuzovic, M., Nikezic, D., Vucic, D., Zeremski, T, Stankovic, M., Kostic, D. (2016). Transfer factors of natural radionuclides and $137 \mathrm{Cs}$ from soil to plants used in traditional medicine in central Serbia. $J$. Environ. Radioact. 158-159,81-88,doi.10.1016/ j.jenvrad.2016.03.028

Faydaoğlu, E., Sürücüoğlu, M. (2011). History of the Use of Medical and Aromatic Plants and their Economic Importance. Kastamonu University Journal of Forestry Faculty 11(1): 52-67

Gazioğlu, C. (2018). Biodiversity, Coastal Protection, Promotion and Applicability Investigation of the Ocean Health Index for Turkish Seas. International 
Journal of Environment and Geoinformatics, 5(3), 353-367, doi.10.30897/ijegeo.484067.

International Atomic Energy Agency (1994) Handbook of parameter values for the prediction of radionuclide transfer in temperate environments. Technical reports series no. 364. Vienna

Jazzar, M. M., Thabayneh, K.M. (2014). Transfer of Natural Radionuclides from Soil to Plants and Grass in the Western North of West Bank EnvironmentPalestine. Int. J. of Environ. Monit. and Analysis. 2(5), 252-258. doi.10.11648/j.ijema.20140205.14

Jevremovic, M., Lazarevic, N., Pavlovic, S., Orlic, M. (2011). Radionuclide concentrations in samples of medicinal herbs and effective dose from ingestion of ${ }^{137} \mathrm{Cs}$ and natural radionuclides in herbal tea products from Serbian market. Isotopes in Environ. and Health Studies, 47(1), 87-92. doi:10.1080/10256016.2011.556723

Jibiri, N. N., Fasae, K. P (2012). Activity concentrations of ${ }^{226} \mathrm{Ra},{ }^{232} \mathrm{Th}$ and ${ }^{40} \mathrm{~K}$ in brands of fertilisers used in Nigeria. Radiation Protection Dosimetry, 148(1), 132-137 https://doi.org/10.1093/rpd/ncq589

McKay, D.L., Blumberg, J.B. (2006). A review of the bioactivity and potential health benefits of peppermint tea (Mentha piperita L.). Phytotherapy research: PTR, 20(8), 619-633. doi.org/10.1002/ptr.1936

Mehra, R., Singh, S., Singh, K.,Sonkawade, R. (2007). ${ }^{226} \mathrm{Ra},{ }^{232} \mathrm{Th}$ and ${ }^{40} \mathrm{~K}$ analysis in soil samples from some areas of Malwa region, Punjab, India using gamma ray spectrometry. Environ. Monit. Assess. 134(1-3), 333-342. doi.10.1007/s10661-007-9624-3

Monica, S., Jojo, P.J., Khandaker, M. U. (2020). Radionuclide concentrations in medicinal florae and committed effective dose through Ayurvedic medicines. Int. J. Radiat. Biol, 96, 1028-1037. doi.10.1080/09553002.2020.1767816

Najam, L., Tafiq, N., Kitah, F. (2015). Estimation of Natural Radioactivity of Some Medicinal or Herbal Plants Used in Iraq. Detection, 3, 1-7.

Nakamura, E., Makishima, A., Hagino, K., Okabe, K. (2009). Accumulation of radium in ferruginous protein bodies formed in lung tissue: association of resulting radiation hotspots with malignant mesothelioma and other malignancies. Proceedings of the Japan Academy. Series B, Physical and biological sciences, 85(7), 229-239.

Özgökçe, F., Özçelik, H. (2004). Ethnobotanical aspects of some taxa in East Anatolia (Turkey). Econ. Bot. 58, 697-704.

Saenboonruang, K., Phonchanthuek, E., Prasandee, K. (2018). Soil-to-plant transfer factors of natural radionuclides (226Ra and $40 \mathrm{~K}$ ) in selected Thai medicinal plants. J Environ Radioact. 184-185, 1-5. doi: 10.1016/j.jenvrad.2018.01.004.

Sarıkaya, S., Öner, H., Harput, Ü.Ş. (2010).Medicinal plants used for the treatment of diabetes in Turkey. $J$. Fac. Pharm, Ankara. 39 (4), 317-342. doi.10.1501/Eczfak_0000000572

Shayeb, M. A., T. Alharbi, M. A. Baloch., O. A. Rahman Alsamhan. (2017). Transfer factors for natural radioactivity into date palm pits. J Environ Radioact. 167, 75-79. doi.10.1016/ j.jenvrad.2016.11.014
Süleyman, H., Demirezer, L. O., Kuruüzüm, A., Banoğlu, Z. N., Göçer, F., Ozbakir, G., Gepdiremen, A. (1999). Antiinflammatory effect of the aqueous extract from Rumex patientia L. roots. Journal of ethnopharmacology. 65(2), 141-148. doi.10.1016/s0378-8741(98)00175-5

Tettey-Larbi, L., Darko, E.O., Schandorf, C., Appiah, A.A. (2013) Natural Radioactivity Levels of Some Medicinal Plants Commonly Used in Ghana. SpringerPlus, 2, Article No. 157. doi.10.1186/2193-1801-2-157

Uchida S., Tagami K. (2007). Soil-to-crop transfer factors of radium in Japanese Agricultural Fields. $J$. of Nuclear and Radiochemical Sciences, 8(2), 137 142. doi.10.14494/jnrs2000.8.137

Ugbede, F.O., Osahon, O.D., Agbalagba, E.O. (2021). Radiological Risk Assessment of ${ }^{238} \mathrm{U},{ }^{232} \mathrm{Th}$ and ${ }^{40} \mathrm{~K}$ in Soil and Their Uptake by Rice Cultivated in CAS Paddy Environment of Abakaliki, Nigeria. Chemistry Africa. doi.10.1007/s42250-021-00244-w

Üstü, Y., Uğurlu, M. (2018). Kekiğin Tıbbi Kullanımı. Ankara Medical Journal. 18 (2) , 242-245. doi.10.17098/amj.435291

Van, H. D., Nguyen, T. D., Peka, A., Hegedus, M., Csordas, A., Kovacs, T. (2020). Study of soil to plant transfer factors of 226Ra, 232Th, $40 \mathrm{~K}$ and $137 \mathrm{Cs}$ in Vietnamese crops J. Environ. Radioact. 223-224, 106416. doi.10.1016/j.jenvrad.2020.106416 